\title{
O Brasil de Montaigne
}

\author{
Frank Lestringant \\ Universidde de Paris IV-Sorbonne
}

\begin{abstract}
RESUMO: Este artigo propõe uma nova leitura dos célebres ensaios dedicados por Montaigne à América e a seus povos, inicialmente à luz da forma retórica da declamação, neles adotada. A comparação entre os Ensaios "americanos" permite ainda evidenciar o lugar privilegiado do Brasil, e de seus Canibais, na reflexão de Montaigne acerca do Novo Mundo, e a composição de uma imagem de todos os seus povos como ao mesmo tempo conformada ao modelo edênico dos Tupinambá e elevada à dignidade dos grandes homens da Antiguidade - "tupinambizada" e "romanizada".
\end{abstract}

PALAVRAS-CHAVE: Montaigne, ameríndios, declamação, primitivismo, Tupinambá, Bom Selvagem, relativismo cultural, filosofia da história

\section{O mundo em movimento}

Poderia ser um paradoxo; não é. Para nós, hoje, a data de 1492 representa o limiar dos tempos modernos, a alvorada de uma época de mutações e progressos em todos os campos - tecnológico, econômico, político, espiritual e artístico. Mas nada disso toca o pensamento de Montaigne. Já que os antigos ignoravam essa metade do mundo que igualmente os ignorava do outro lado do oceano, pode-se pensar que essa descoberta não é nada, comparada ao que permanece escondido e que está por descobrir. "Temo, escreve Montaigne, que tenhamos os 
olhos maiores do que a barriga, e mais curiosidade do que capacidade" (Montaigne, 1965, I, 31, p. 203). E parafraseando o Eclesiastes: "Abarcamos tudo, mas só pegamos vento". Essa constatação desiludida, formulada em 1580, no capítulo "Dos Canibais", terá eco preciso oito anos mais tarde, no capítulo "Dos coches": "Nosso mundo acaba de encontrar um outro mundo (e que nos indaga se é o último de seus irmãos, já que os Demônios, as Sibilas e nós o ignorávamos até o momento?)” (id., III, 6, p. 908). Aqui o importante é o parêntese. Mesmo vozes inspiradas, como as dos demônios e as das sibilas, nada disseram do Novo Mundo. O que pensar, então, das de simples mortais? Que importância dar à opinião corrente? Passada a surpresa da descoberta, instala-se a dúvida de que essa seja realmente a última, e que contribua de modo decisivo para o conhecimento que temos do mundo e de nós mesmos.

A imagem do mundo em movimento expressa perfeitamente o estado de espírito de Montaigne diante das profundas transformações de sua época. A imagem da terra jamais havia exibido tal instabilidade. Por culpa, em primeiro lugar, das grandes navegaçōes, que estilhaçaram o mundo fechado da Idade Média. Já não há mais um único continente, envolvendo o Mediterrâneo central, útero confortável onde se abrigavam as certezas dos antigos, mas uma poeira de ilhotas, arquipélagos, lascas de terra, que vogam à deriva num oceano desmesuradamente ampliado.

A figuração mais precisa da descoberta da América e das transformações que provocou talvez seja a página do capítulo "Dos Canibais" em que Montaigne fala de "sua" Dordonha e da invasão do Médoc pelas dunas. Aparentemente, trata-se de tudo menos do Novo Mundo. Mas é aí que a topografia mostra sua pertinência. Pela extrema atenção dada ao detalhe local, pela agudeza de um olhar voltado para a paisagem próxima e concentrado nela, Montaigne pode compreender o que se passa numa escala totalmente diversa, em terras longínquas. O Rio Dordonha 
Revista de Antropologia, São Paulo, USP, 2006, v. 49 no 2.

roendo suas margens, o Médoc afogado na areia, esses fenômenos familiares, contanto que sejam considerados com a inteligência necessária e sem perder, evidentemente, o senso de proporção, informam mais do que as longas viagens acerca do seísmo ocorrido a milhares de léguas, quando da conquista da América pelos espanhóis.

É apenas nessa escala aproximada que se pode apreender um objeto. "Não consigo fixar meu objeto", escreve Montaigne algures: "Ele anda incerto e cambaleante, naturalmente ébrio. Tomo-o neste ponto, como é, no instante em que me distraio com ele" (id., III, 2, p. 805). Ao mundo em movimento do século XVI corresponde o movimento incessante da investigação, saltando de uma singularidade para outra, de um momento para outro. A coincidência entre os dois movimentos é sempre fugidia. Reduz-se ao instante. A apreensão é transitória, a fixação, momentânea. O percurso dos Ensaios se assemelha a uma navegação alinhando ancoragens provisórias, seguindo rotas sinuosas e quase sempre imprevisíveis.

Montaigne está sempre pronto a recorrer a lugares retóricos, que nunca são nele mais do que balizas transitórias, flutuantes, abandonadas quase que imediatamente após terem sido consideradas. Em vez de terem por função reduzir o desconhecido ao conhecido e o escandaloso ao familiar, mitos como os da Atlântida, da idade de ouro, da república ideal ou do filósofo nu, evocados em "Dos Canibais", servem apenas, finalmente, para provar o caráter irredutível de uma alteridade inédita e, a bem dizer, impossível de apreender. Todos contêm uma porção limitada de verdade, e uma vasta porção de mentira. Todos são úteis para pensar o impensável. Mas nunca passam de aproximações, que é preciso corrigir após terem sido expressas e que, de todo modo, se contradizem e se anulam quando postas em seqüência, como Montaigne se compraz em fazer. Os topoi valem, assim, pelo que são, ficções engenhosas que permitem representar o real, ou melhor, imaginá-lo, por aproximações sucessivas. Logo esses pontos de apoio se tornam obstáculos para um 
pensamento em movimento. Como um navio carregado por uma forte deriva, eis que o texto arrasta sua âncora ou rompe sua corrente.

\section{A experiência brasileira de Montaigne}

Para quem o lê de modo superficial, ${ }^{1}$ Montaigne parece pender constantemente para o devaneio primitivista. ${ }^{2}$ Os Canibais de que nos fala Montaigne - no caso, os Tupinambá do Rio de Janeiro, cujos ferozes feitos haviam sido divulgados por Thevet e depois Léry alguns anos antes - ignoram todas as invençóes e, portanto, todos os males que caracterizam nossa sociedade. Como tantos outros antes dele, poetas e viajantes, de Ovídio a Ronsard e de Marco Polo a Cristóvão Colombo, e como Shakespeare, mais tarde, que nele se inspirará em $A$ tempestade, pela voz do velho Gonzalo, Montaigne expõe a série privativa da idade de ouro:

Trata-se de uma nação, diria eu a Platão, na qual não existe nenhuma espécie de comércio; nenhum conhecimento das letras; nenhuma ciência dos números; nenhum magistrado ou superioridade política; nenhuma vassalagem, riqueza ou pobreza; nenhum contrato, nenhuma sucessão, nenhuma partilha; nenhuma ocupação que não seja ociosa; nenhuma consideração do parentesco, a não ser o de todos; nenhuma roupa; nenhuma agricultura; nenhum metal; nenhum vinho ou pão. As próprias palavras que significam mentira, traição, dissimulação, avareza, inveja, maledicência ou perdão lhes são desconhecidas. (Montaigne, I, 31, p. 206)

E eis os Canibais elevados à categoria de tipo ideal, assemelhados a "todas as pinturas com que a poesia aformoseou a idade de ouro". Nada de muito novo nessa litania. Mas Montaigne não se deixa enganar pelo lugar-comum. Sabe muito bem que, na verdade, esses índios prati- 
Revista de Antropologia, São Paulo, USP, 2006, v. 49 no 2.

cam a agricultura, fiam e tecem algodão, praticam escambo, possuem um sistema de parentesco extremamente complexo etc. De resto, na seqüência do capítulo, ele não fica preso à negação inicial que faz do selvagem, o não-civilizado absoluto. Ainda que, para a decepção de sonhadores e poetas, ele reconstrua a figura positiva do Brasileiro, convocando todas as circunstâncias materiais que farão com que ele apareça corporificado na trama do ensaio: sua rede e suas armas, sua comida e sua bebida "feita de uma certa raiz" e "da cor de nossos vinhos claretes", seu bastão de ritmo, e também sua dança, seus gestos e posturas, sua música, e uma poesia lírica digna das graças anacreônticas.

Ou seja, o lugar-comum primitivista não passava de mera etapa no raciocínio, assim como a referência à república ideal de Licurgo e Platão. A fórmula negativa representa o momento da tábula rasa, a partir do qual se torna possível a reconstrução antropológica. Pois Montaigne estabelece um quadro de referência apenas para extrapolá-lo e escapar dele. A deriva supõe um ponto de apoio inicial. Se quisermos negar as idéias preconcebidas, é preciso começar por retomá-las, como lembrança e como baliza.

O fato de Montaigne listar lugares-comuns, para melhor afastar deles em seguida seu próprio pensamento, não deve levar a concluir que se trata de puro gosto pela destruição de falsas evidências - pela desconstrução, diriam hoje em dia. Nesses deslocamentos e nessa viagem contínua do pensamento existe, sim, a busca de uma terra firme do sentido. Até então, a inteligência se move em solo instável, terra movediça ou mar móvel.

Ao fazê-lo, Montaigne não volta as costas para o real. O Novo Mundo, nele, não é nem ficção nem mera alegoria. Pois existe, de fato, uma experiência brasileira de Montaigne, indireta, mas ainda assim experiência, que passa pelos cinco sentidos. Montaigne tem a experiência do Brasil, de certo modo, por meio de testemunhos e objetos. 
No terceiro andar da torre redonda onde costumava ficar, sentado e ditando enquanto controlava com o canto do olho a criadagem, sua "livraria”, isto é, sua biblioteca, abria-se em círculo a todos os horizontes. Ao sul, estava a Espanha, a leste, a Itália, ao norte, a França, país perigoso, sempre agitado por guerras civis, e a oeste, Bordeaux e o oceano. Foi nesse refúgio, que era ao mesmo tempo um observatório, que ele leu os relatos do Brasil feitos pelos viajantes franceses André Thevet e Jean de Léry, e também os cronistas espanhóis Francisco Lopez de Gomara e Gonzalo Fernandes de Oviedo, e, sobretudo, a Brevíssima relação da destruição das Índias, do dominicano Bartolomé de las Casas, requisitório inflamado contra os crimes da Conquista e profecia apocalíptica da destruição da Espanha. À boa distância do Novo Mundo, mas de frente para ele, por assim dizer, Montaigne ocupava o melhor posto de observação possível, com o distanciamento necessário em relação ao objeto, tanto em termos cronológicos quanto espaciais. Menos de um século o separava de Colombo, meio-século de Cortez e Pizarro. Apenas um oceano e três meses de travessia se interpunham entre ele e a costa do Brasil.

Afora isso, além dos livros, havia outras ligações entre as duas margens do Atlântico. Um dos criados do castelo de Montaigne tinha estado no Brasil na juventude, uns dez ou doze anos entre os Tupinambá, na época em que Villegagnon fundava, na entrada da Baía de Guanabara, uma efêmera "França Antártica". Montaigne costumava interrogar esse "homem simples e grosseiro", cuja ausência de preconceitos o tornava apto "a fornecer [um] testemunho verdadeiro". Para corroborar seus dizeres, o gabinete do castelo de Montaigne guardava uma coleção invejável de americana: ao lado de redes e fios de algodão, havia ali espadas-bordunas de ponta espalmada e afiada e pulseiras de madeira "com que eles cobrem os pulsos em combate". E bastóes de ritmo, caniços ocos com que os dançarinos batiam no chão para marcar a cadência, os 
quais Montaigne é o primeiro a descrever com certa precisão, sugerindo que funcionavam como ressoadores.

Essa realidade longínqua, tornada presente em traços e fragmentos, realidade sinedóquica depositada entre as paredes de Saint-Michel de Montaigne, entra em jogo em "Dos Canibais" com a retórica da declamação.

\section{A “declamação" dos Canibais}

A declamação é o espaço indefinido em que o pensamento pode dar livre curso a si mesmo, e Montaigne adota a labilidade, a liberdade de tom e de movimento da retórica da declamação. Termo ao mesmo tempo mais amplo e mais técnico do que "paradoxo" (ver Dandrey, 1997, pp. 137-73), "3 "declamação" designa o exercício de desenvolvimento oratório acerca de um tema dado que os retores recomendavam para a formação ou para a prática do orador. "O 'real irreal', esse é o objeto psicológico, judiciário e retórico" do declamador (Quignard, 1990, cap. III, p. 15). Na declamação, "as duas noçôes essenciais, interligadas, são a de exercício e a de ficção" (Chomarat, 1981, II, p. 935). A declamação se define por sua completa liberdade, o que faz dela o instrumento privilegiado para uma reflexão moral sem preconceitos. Seu ponto de vista é móvel, a identidade do locutor, sempre fugaz.

Por razões ligadas à instabilidade do período, às profundas transformaçôes que o conturbam e à enorme resistência que enfrentam as novas idéias, o Renascimento fez da declamação um de seus modos de expressão favoritos. A declamação irriga toda a literatura do século XVI, do Elogio da loucura de Erasmo aos Ensaios de Montaigne. Thomas More, na Utopia, escreveu uma declamação com suporte geográfico. A obra de François Rabelais é marcada por declamações: o elogio das dívidas por 
Panurgo, o hino à erva chamada Pantagruélion, os elogios de "senhor Gaster, primeiro mestre em artes do mundo". Étienne de la Boétie, o amigo falecido de Montaigne, compôs, no Discurso da servidão voluntária, uma declamação oratória febril, de lógica implacável (Lafond, 1984, p. 736). ${ }^{4}$ Vários capítulos e fragmentos de capítulos dos Ensaios são declamaçóes (Tournon, 1983, pp. 203-28), entre os quais podem ser mencionados o elogio da gravela, em "Da experiência" (Montaigne, 1965, III, 13), e o caso mais picante do arrazoado em favor do "membro indócil", em "Da força da imaginação" (id., I, 21). Mas o melhor exemplo de declamação em Montaigne é, sem dúvida, "Dos Canibais", apologia dos antropógafos livres do Brasil, nos quais revivem a idade de ouro dos antigos e a república ideal sonhada por Platão e Plutarco.

A extensão do gênero e sua plasticidade se prestam a todas as audácias, bem como a todas as esquivas. À sombra temível dos Canibais, está a grande figura da Loucura. Uma linha de loucura liga Erasmo a Montaigne, através de um século XVI que dela viu outras muitas formas, muitas mais virulentas e mais trágicas. A loucura erasmiana é branda, crítica, supóe o desdobramento e o jogo teatral (ver Fumaroli, 1972, pp. 92-8). Ora, o selvagem tem muito a ver com o louco. ${ }^{5} \mathrm{E}$, justamente, entre o Elogio da loucura e "Dos Canibais", existe um intermediário, La pazzia (em italiano, "a loucura"), "tratado bastante agradável em forma de Paradoxo". Essa obra anônima, publicada em Veneza em 1540, introduz, bem antes de Montaigne, os povos nus do Novo Mundo no espaço crítico da declamação. Como em Erasmo, a Loucura tem a palavra. E pode dizer tudo, a começar por contrariar o senso comum. E não teme desmentir os mais eruditos, afirmando, por exemplo, que o "povo recentemente descoberto na Índia Ocidental" vivia feliz, "sem leis, sem letras, e sem nenhum sábio". Bem-aventurados, eles desprezavam o ouro e as "jóias preciosas", não conheciam "nem a avareza, nem a ambição, nem qualquer outra arte". Alimentando-se "dos frutos que a terra pro- 
Revista de Antropologia, São Paulo, USP, 2006, v. 49 no 2.

duzia sem artifício [...] tinham, como na República de Platão, todas as coisas em comum, inclusive as mulheres e as criancinhas, que desde o nascimento eles alimentavam e criavam em comunidade, como se fossem todos seus próprios". ${ }^{6}$

A concordância pontual com Platão não o impede de se contrapor àquele que desejara que os filósofos fossem reis, ou, no mínimo, que os reis se tornassem filósofos. La Pazzia o contradiz abertamente: "A isso, eu responderia que não, que seria para toda gente a pior infelicidade, a maior calamidade, o ver-se cair nas mãos de tais filosofastros e homens sabidos demais". 7 Prova disso são os espanhóis, que, "com seu exagerado saber, seus grandes refinamentos e suas insuportáveis leis e éditos", encheram "de milhares de males, pesares e fadigas" aquela terra antes abençoada pelos deuses.

O estilo da declamação se evidencia em Montaigne pelas hipérboles laudativas e sentenças sem réplica, como a fórmula que se tornou o slogan do relativismo: "Cada qual chama de barbárie o que não é de seu costume". Pode ser reconhecido sobretudo na desenvoltura com que o mundo exótico é calcado no mundo clássico, desenvoltura essa que se dirige, novamente, a Platão: "Trata-se de uma nação, diria eu a Platão, na qual [...]" Platão, transportado ao país dos canibais, certamente perderia seu grego. No mínimo se surpreenderia diante do fato de uma sociedade poder, contrariamente àquela que ele havia imaginado, "manter-se com tão pouco artifício e solda humana” (Montaigne, 1965, I, 31, p. 206). Desmentido contundente, feito em nome da experiência, à erudita e complexa arquitetura da República. Essa incongruência calculada traz a marca de La Pazzia. Nesse sentido, Todorov não está longe da verdade quando fala em "burla" a propósito desse capítulo de Montaigne. Este apenas atenuou a ironia um tanto pesada de seu modelo, realçando-a na tirada final a respeito da falta de calças. O veredicto a respeito da história recente, por sua vez, retoma, de modo mais sério, o do anônimo 
veneziano: com a conquista da América, o artifício triunfou sobre a natureza, para a grande desgraça dos povos do Novo Mundo.

O estilo da declamação se revela com toda força em Montaigne, finalmente, no espantoso diálogo entre o rei da França e os selvagens que conclui o ensaio. A palavra já não pertence à Loucura nem a Platão, mas ao Canibal. Um Canibal triplicado, superlativo, de certo modo:

Três deles, ignorando o que custaria um dia a seu repouso e felicidade o conhecimento das corrupções de cá, e que esse contato geraria sua ruína, que suponho já avançada (pobres deles que se deixaram levar pelo gosto da novidade e deixaram a brandura de seu céu para vir ver o nosso), estiveram em Rouen, quando ali estava o finado rei Carlos IX: o rei falou longamente com eles, foram-lhes mostrados nossos modos, nossa pompa, a forma de uma bela cidade e, depois disso, alguém lhes pediu sua opinião, querendo saber deles o que haviam nisso considerado mais admirável. Eles responderam três coisas.

Montaigne ama as tríades (Starobinski, 1982, p. 159). Nos Ensaios há três livros e pode-se distinguir neles três estratos de redação e três épocas. Vários de seus capítulos baseiam-se no número três, como "De três mulheres" (Montaigne, 1965, II, 35) e "De três comércios" (id., III, 3). A biblioteca de Montaigne se encontrava no terceiro e último andar de uma torre, ${ }^{8}$ que possui "três vistas de rica e ampla perspectiva" (ibid.). Entre essas três aberturas, antigamente, três grandes estantes cobriam as paredes. No teto da biblioteca, três vigas cobertas de inscrições delimitam três espaços, separados por duas vigas mestras igualmente "inscritas". ${ }^{9}$ Em Rouen, diante do jovem rei Carlos IX, há três Canibais, e esses Canibais, interrogados, fornecem três respostas.

O número três, que talvez seja, em Montaigne, uma herança das disputas escolásticas, abre a possibilidade de uma escapatória: permite su- 
Revista de Antropologia, São Paulo, USP, 2006, v. 49 no 2.

perar o antagonismo congelado e inviabiliza qualquer julgamento maniqueísta. Isso posto, as circunstâncias da entrevista são as mais vagas. Como é de seu costume nos Ensaios, Montaigne evita indicar uma data precisa. A fórmula "em Rouen, quando ali estava o finado rei Carlos IX" leva a supor o outono de 1562, logo após a retomada da cidade aos protestantes, durante a primeira guerra de Religião.

Das três "respostas" que os três Canibais formulam - que na verdade são questôes -, duas foram conservadas por Montaigne, que esqueceu a terceira. É como que um convite dirigido ao leitor, chamado a cooperar e imaginar a resposta que falta. Jean-Jacques Rousseau propóe uma no final do Discurso sobre a origem da desigualdade. O esquecimento de Montaigne, quer seja real ou simulado, tem por efeito paradoxal intensificar a presença de uma cena talvez inventada, certamente idealizada (Montaigne, 1965, I, 31, p. 214), ${ }^{10}$ do mesmo modo que a interposição, entre os selvagens e ele, de um intérprete bronco e lento na tradução "impedido por sua idiotice, reclama ele, de captar minhas conjeturas".

De qualquer modo, as duas observações restantes bastam, e não requerem nenhuma seqüência ou complemento. $\mathrm{Na}$ verdade, trata-se do mesmo escândalo denunciado duas vezes, primeiro em seu aspecto político - o rei criança de que se lembra Pascal - e, em seguida, em seu aspecto econômico - os pobres morrendo de fome à porta dos ricos. Essas duas "respostas" constituem duas variações sobre o paradoxo da Servidão voluntária. Tal como foi exposto por La Boétie em seu Ensaio, o paradoxo pode assim ser resumido: é impossível para um homem sozinho, "nu e abatido", sujeitar todo um povo se esse povo não se sujeitar primeiro por si mesmo. "É o povo que se sujeita, que corta a própria garganta, que, tendo a escolha entre ser servo ou ser livre, abandona sua liberdade e aceita o jugo." La Boétie analisa em seguida os meios - especialmente a pirâmide dos interesses - de que o tirano se vale para se manter no poder e fazer com que o corpo social, de cumplicidade em 
cumplicidade, acorrente-se por conta própria. O objeto do Discurso é, fundamentalmente, a política enquanto tal (ver Clastres \& Lefort, 1976, pp. 229-307). Definitivamente, La Boétie se espanta com o espetáculo da obediência. Os Canibais com quem Montaigne se encontrou em Rouen também.

Entre a primeira e a segunda respostas dos Canibais, observa-se a passagem da surpresa à cólera, cabendo ao qualificativo "estranho", deliberadamente repetido, refletir ambos os sentimentos. Inicialmente, os embaixadores do Novo Mundo exprimem seu espanto diante dos "homens grandes, barbados, fortes e armados" que se sujeitam a "obedecer a um meninote", referindo-se a Carlos IX, rei adolescente, então com 12 anos, cercado pelos sólidos Suíços de sua guarda. A passagem lembra, de forma mais contida, e também mais irônica, a indignação oratória da Servidão voluntária diante do vício, "ou melhor, malfadado vício", que faz com que "um sem número de pessoas" suporte a tirania "de um só homúnculo, nas mais das vezes o mais covarde e efeminado da nação" (La Boétie, 1987, p. 35). ${ }^{11}$

Paradoxo político de que decorre, na ordem social, o que está contido na segunda "resposta" do Canibal. Na verdade, trata-se de um ato de acusação claramente formulado:

[...] segundo, que eles tinham percebido que havia entre nós homens gordos e fartos de todas as espécies de comodidades, e que suas metades (eles possuem um modo em sua língua que diz serem os homens metade uns dos outros) mendigavam à porta destes, consumidos pela fome e pela pobreza; e achavam estranho que essas metades tão necessitadas aceitassem sofrer tamanha injustiça, e não agarrassem os outros pelo pescoço ou ateassem fogo em suas casas. (Montaigne, 1965, I, 31, p. 214) 
Revista de Antropologia, São Paulo, USP, 2006, v. 49 no 2.

Com "Dos Canibais", Montaigne inventa o que Michel de Certeau chamou de "heterologia", isto é, um discurso do outro, que é ao mesmo tempo discurso sobre o outro e discurso em que o outro fala. Na base da operação etnográfica, a heterologia é uma "arte de jogar com dois lugares", um modo de estimar num lugar o que falta no outro (Certeau, 1985). ${ }^{12}$ A heterologia provê um espaço intermediário, um palco reversível, em que a última palavra não pertence necessariamente ao sujeito primeiro do discurso, e a crítica não poupa o enunciador, ele mesmo atingido por ricochete. Ora, a declamação é, em essência, uma heterologia. Ocupa um intervalo, fabrica um afastamento, em que o risco do efeito bumerangue da palavra livre é plenamente assumido.

"Os direitos que nos deu a natureza", para retomar uma expressão de La Boétie (1987, p. 41), ${ }^{13}$ e que deveriam inclinar os homens a uma "fraterna afeição", obrigam-nos a levar a sério as ameaças dos três selvagens, escandalizados, primeiro, pelo rei-criança cercado por sua guarda armada e, segundo, pela desigualdade gritante que observam nas ruas de Rouen. Sua conclusão é, no mínimo, atemorizante: a perspectiva de um levante popular, com os pobres pulando no pescoço dos ricos e incendiando-lhes as casas.

Uma tal eventualidade nada tinha de improvável. Montaigne ainda se lembrava da revolta da gabela, ${ }^{14}$ no reinado de Henrique II, e da feroz repressão que acarretou, especialmente em Bordeaux, que talvez se encontre na origem das frases inflamadas de La Boétie. ${ }^{15}$ Torna-se então necessária a boutade final sobre as "calças" para dissipar a ameaça. Assim, até na virulência oratória que a anima, a declamação dos "Canibais" se apresenta como parente próxima do Discurso da servidão voluntária.

Mas a declamação dos "Canibais" possui também um alcance religioso. Tratando de um tema delicado, o capítulo inflete a antropofagia ritual dos Tupinambá no sentido de um "canibalismo de honra", troca verbal, mais do que carnal, entre a assembléia dos comensais e o prisio- 
neiro imolado. ${ }^{16}$ Diante da evidência simbólica da refeição de carne humana, sugere-se um paralelo entre o sacrifício em terras selvagens e a teofagia sagrada dos cristãos, de modo implícito, nas palavras desafiadoras do prisioneiro logo antes de morrer: "Estes músculos, diz ele, esta carne e estas veias são os vossos, tolos que sois; não percebeis que a substância dos membros de vossos ancestrais aí permanece: saboreai bem, e encontrareis o gosto de vossa própria carne" (Montaigne, I, 31, p. 212). "Invenção", conclui Montaigne, "que em nada sabe a barbárie." O prisioneiro retido pela corda se expressa um pouco como Jesus Cristo no Cenáculo, quando da consagração do pão e do vinho. Verifica-se aqui o mesmo uso do dêitico que na instituição da Ceia - "Isto é meu corpo", ou melhor, neste caso, "o vosso corpo" -, a mesma insistência na "substância" nutriz e salvadora do corpo ofertado e compartilhado. Como observa George Hoffmann, num artigo instigante, não se pode afastar uma ligeira intenção paródica nessa fala transcrita em estilo direto (Hoffmann, 2002, pp. 207-21).

Ao fazer isso, Montaigne vai mais longe do que os protestantes, que, embora releguem os católicos adeptos da transubstanciação à categoria dos Canibais, evitam sugerir a analogia entre o prisioneiro tupinambá à beira da morte e Cristo na véspera da Paixão. Montaigne completa o paralelo com uma imagem que se afasta da iconografia dos viajantes. Hans Staden, André Thevet e Jean de Léry, todos de acordo nesse ponto, representavam o prisioneiro com uma corda amarrada em torno da cintura, com os demais movimentos liberados, e lançando pedras e tocos contra a multidão, que às vezes chegava a ferir nesse simulacro de combate. Montaigne, ao contrário, apresenta uma vítima subjugada e impotente, com os braços amarrados em cruz:

O dono do prisioneiro [...] amarra-lhe uma corda num dos braços, [C] cuja ponta segura a uma distância de alguns passos, para evitar ser atin- 
Revista de Antropologia, São Paulo, USP, 2006, v. 49 no 2.

gido, [A] e dá a seu melhor amigo o outro braço, para segurar do mesmo modo; e ambos, diante de toda a assembléia, matam-no a bordunadas. (Montaigne, 1965, I, 31, p. 209)

Se bem compreendemos a descrição de Montaigne, o prisioneiro tem os braços amarrados e mantidos em posição cruciforme. Falha de memória ou intenção deliberada de transformar o documento etnográfico para aproximá-lo da Crucificação? Embora pequena, a transformação parece efetivamente revelar uma intenção e sugerir a analogia entre os sacrifícios praticados em culturas afastadas no espaço e no tempo. ${ }^{17}$

Montaigne, no entanto, não dessacraliza de modo algum a Eucaristia, como tampouco retira a substância do canibalismo ritual dos Brasileiros. Sua sedução analógica toma uma via original, muito diferente daquela adotada pelos calvinistas, que identificavam católicos e canibais para melhor reduzir o sacramento reformado a puro símbolo de aliança, signo sem significante. Montaigne, ao contrário, insiste na presença real do sacrificante-sacrificado, que coincidem no Cristo e, em larga medida, também no prisioneiro tupinambá, enfatizando assim a proximidade das substâncias.

Mas tudo isso permanece implícito, mais sugerido do que dito, e sobretudo alheio a qualquer intenção polêmica, numa descrição de aparência (falsamente) objetiva, que se situa nos antípodas da invectiva.

\section{"Dos Canibais" e "Dos coches": duas declamações em eco}

Nada mais natural do que aproximar os dois capítulos dos Ensaios dedicados à descoberta e exploração do Novo Mundo, "Dos Canibais" e "Dos coches". Menos de uma década os separa: $1580-1588 .{ }^{18}$ No intervalo, Montaigne viajou para a Alemanha, a Suíça e a Itália. E leu os franceses 
e os espanhóis: depois de Léry e Thevet, Gomara e Las Casas. Com o recuo, a conquista da América assume suas verdadeiras dimensões de cataclisma: dezenas de milhões de mortos, povos aniquilados de um dia para o outro, civilizações brilhantes definitivamente destruídas. Cataclisma de causas puramente humanas, que constitui um dos maiores escândalos da História. Montaigne enfatiza, numa enumeração vertiginosa, a desproporção entre meios e fins: "Tantas cidades arrasadas, tantas nações exterminadas, tantos milhões de povos massacrados, e a mais rica e mais bela parte do mundo destruída em nome do negócio de pérolas e pimenta: mecânicas [=vis] vitórias!". A inflexível lei do capitalismo comercial, a louca corrida pelos metais preciosos, a exploração sem limites das populações indígenas, escravizadas de fato, quando não de direito, foram responsáveis por uma catástrofe ímpar na História.

"Dos Canibais" tratava da idade de ouro dos livres Brasileiros do litoral atlântico. "Dos coches" denuncia a destruição do Novo Mundo pelos Espanhóis, em particular a ruína total dos impérios asteca e inca. $\mathrm{O}$ encadeamento entre um capítulo e o outro torna mais evidente o contraste entre a gênese e o apocalipse, entre os primórdios serenos da História e seus tumultos e acidentes brutais. Nesse sentido, o Éden brasileiro em "Dos Canibais" e o Inferno da Conquista espanhola, tal como duramente descrita em "Dos coches", formam um díptico. ${ }^{19}$

A aproximação se impõe ainda mais na medida em que é autorizada por Montaigne, que em "Dos coches" remete explicitamente ao exemplo dos Canibais - "prova disso são meus Canibais" (Montaigne, 1965, III, 6, p. 911). O que está em questão, nessa passagem, é a resposta dos índios à brutalidade verbal dos conquistadores, convencidos de seus direitos e cinicamente confiantes na superioridade de suas armas.

Os dois capítulos seguem caminhos paralelos. Para retomar a expresão de Roger Caillois a respeito das Cartas persas de Montesquieu, a mesma "revolução sociológica" se opera nos dois ensaios (Caillois, 1947, I, 
p. v). A palavra passa do observador para o observado, e o suposto bárbaro torna-se juiz do europeu. Esse refluxo da palavra para o emissor se opera segundo modalidades ligeiramente diferentes em cada caso. A reversão do ponto de vista é ilustrada, em "Dos Canibais", pela inversão oral, e, em "Dos coches”, é apresentada no encontro entre os índios da terra firme e os conquistadores.

Tal como é descrito por Montaigne, o Canibal possui o estranho hábito de falar mais do que comer, proferir mais do que ingerir. Prova disso são as réplicas firmes que opõe às férreas certezas do europeu na entrevista em Rouen, que conclui o ensaio I, 31. Prova disso também são as palavras desafiadoras que os guerreiros, prestes a serem imolados para a fome de vingança de seus inimigos, pronunciam à beira da morte: "eles os desafiam, injuriam-nos, acusam-nos por sua covardia e pelas batalhas perdidas contra os seus" (Montaigne, 1965, I, 31, p. 212). Mais ainda, segundo Montaigne, que folheou Thevet e Léry e contemplou as gravuras que ilustram as descrições do Brasil, "os que os descrevem no momento da morte" representam-nos "cuspindo no rosto daqueles que os matam e fazendo caretas". ${ }^{20}$ Várias gravuras mostram o prisioneiro amarrado pela cintura, ameaçando com gestos e palavras a assembléia dos vencedores, que se mantêm prudentemente a distância no exato instante em que a borduna empenada e pintada vai se abater sobre sua cabeça (Staden, 1557, II, p. 29; De Bry, 1592, p. 125; 1593, p. 85). ${ }^{21}$ Estranho Canibal esse, que faz caretas, vocifera e cospe na hora de morrer!

A atividade oral do antropófago brasileiro é, portanto, invertida. $\mathrm{O}$ movimento natural que leva o alimento de fora para dentro torna-se projeção centrífuga, que afasta do corpo selvagem a ameaça mortal e a cusparada. A violência encarnada no Canibal se separa dele, por intermédio de uma palavra livre e verídica, e atinge em cheio o observador europeu, cuja sociedade civil, atravessada pelo antagonismo entre ricos e pobres, está ameaçada de rompimento. Na "derrota triunfante" 
(Montaigne, 1965, I, 31, p. 211)22 do Canibal agonizante, cercado por seus inimigos, que ele domina do alto de seu desprezo e de sua coragem, como na profecia incendiária que três de seus irmãos, no meio "de uma bela cidade", dirigem ao jovem rei Carlos IX e à corte em visita a Rouen, é a mesma palavra vingativa e devastadora que reflui, lançada pela vítima sobre o agressor.

O capítulo "Dos coches" repete esse movimento de reviravolta pela descrição da "intimação" ou requerimiento. Esse rito jurídico, por intermédio do qual os conquistadores espanhóis intimavam os índios diante de si, na presença de um notário, a se converterem e a se submeterem (ver Bataillon, 1959, pp. 353-67), constitui o eixo de inversão do olhar e da palavra. Palavra que, proferida com arrogância pelos conquistadores, passa para seus ouvintes, e é imediatamente captada por essas "crianças" nuas e desarmadas que os admoestam, exibindo uma eloqüência de rara energia. Ao tomar emprestada de López de Gomara a decrição desse rito caricatural, Montaigne reverte em favor das vítimas um texto que visava à apologia dos algozes. São os próprios cronistas espanhóis que lhe fornecem os meios de devolver a palavra aos índios.

Em Gomara, a coisa acaba mal para os índios eloqüentes demais nesse caso, índios da província de Zenu, encontrados pelo "doutor" Enciso em 1509, e que tiveram a infelicidade de lhe resistir. No final, todos foram massacrados ou escravizados (Lopez de Gomara, 1587, pp. 234-5 $\mathrm{v}^{\circ}$ ). Em lugar desse epílogo, em tudo conforme a lógica sangrenta da Conquista, Montaigne corta, insere uma tirada irônica "Eis aí um exemplo do balbuciamento dessa infância" - e conclui com a derrota dos espanhóis. Estes, na realidade, quando não encontraram ouro, pelo menos conseguiram escravos e alimento.

"Dos coches" remete, tanto quanto "Dos Canibais", à retórica da declamação. Em ambos os capítulos, uma mesma proposição paradoxal e hiperbólica é ora sustentada por uma leve ironia, ora por um tom 
oratório e solene. Também aqui a veemência do estilo atinge seu paroxismo gradativamente, e culmina numa queda abrupta. Mais uma vez, a posição relativista de Montaigne não exclui a condenação moral, o pathos que acompanha a passagem da argumentação à imprecação:

A resposta foi a seguinte: que, quanto a serem pacíficos, não aparentavam sê-lo, se é que o eram. Quanto ao seu rei, já que perguntavam, devia ser um indigente, e necessitado, e aquele que havia feito tal distribuição, homem afeto às dissensões, que dera a um terceiro algo que não era seu, para colocá-lo em questão contra os antigos possuidores. Quanto aos víveres que lhes forneceriam: ouro tinham pouco, e era coisa que não valorizavam nada, já que era inútil para a sua vida, que todo seu cuidado estava tãosomente em passá-la de modo feliz e agradável; mas que o que pudessem encontrar, excetuando o que era empregado a serviço de seus deuses, que o tomassem ousadamente. Quanto a um só Deus, haviam apreciado o discurso, mas não queriam mudar sua religião, que tão bem lhes servira por tanto tempo, e que tinham o costume de só aceitar conselhos de seus amigos e conhecidos. Quanto às ameaças, que era sinal de insensatez sair ameaçando gente cujos recursos e natureza lhes eram desconhecidos. Assim, que se apressassem em deixar imediatamente sua terra, pois não costumavam levar por bem os julgamentos e condenaçôes de gente armada e estrangeira; ou fariam com eles como com os outros, mostrando-lhes as cabeças de uns homens punidos em volta de sua cidade. (Montaigne, 1965, III, 6, p. 911)

O efeito bumerangue da declamação em "Dos Canibais” é expresso do modo mais preciso e mais concreto concebível na canção de agonia do prisioneiro: "Estes músculos, esta carne e estas veias", que ireis comer, "são os vossos", retruca o canibal expectorante aos vencedores do dia (id., I, 31, p. 212). De passagem, como observamos acima, ele pare- 
ce parodiar Jesus Cristo no Cenáculo, no momento da consagração do pão e do vinho. Mas, em vez de anunciar um evangelho de paz e amor, insufla a guerra e clama pela vingança contra seus algozes, que logo seriam eles mesmos aprisionados pelo ciclo do sacrifício, tornados vítimas da violência que haviam detonado. A ameaça que se dirige em seguida aos habitantes de Rouen e à corte em visita não é puramente formal. Ela contém a possibilidade de uma reviravolta.

Em "Dos coches", a reviravolta potencial, significada pela indicação das "cabeças de uns homens punidos em volta de sua cidade", é empurrada para o fim da História e para fora dela. Pois, nem bem termina a cena da intimação, uma chuva de calamidades despenca sobre o Novo Mundo, precocemente envelhecido pela brutalidade dos conquistadores. A sobriedade do relato, de quatro longas páginas, acentua o efeito cumulativo da catástrofe. O próprio excesso gera um desequilíbrio marcado pela imagem-chave na última frase do capítulo, do Inca caindo de seu trono de ouro. Esse desequilíbrio acusador prepara o caminho para uma reviravolta moral. Na verdade, as agonias gêmeas de Atahualpa, o Inca martirizado após seu batismo, e de Cuhautémoc, o imperador asteca que sucedeu Montezuma e cujas pernas Cortez mandou queimar, repetem a do prisioneiro "triunfante" do primeiro ensaio. Dignos dos magnânimos soberanos que ambos foram, seus finais são eloqüentes. Denunciam a iniqüidade do suplício e fazem prever uma reparação pelo sangue. Os tesouros extorquidos, que foram engolidos pelo oceano, e a morte dos algozes em guerras civis - "com que se comeram entre si" fecham o ciclo das violências, com uma última troca entre o carrasco e sua vítima. Mais uma vez, a voracidade oral serve para expressar a violência voltando-se contra si mesma. Os conquistadores que praticaram em Cuhautémoc a culinária do vivo, já denunciada em "Dos Canibais”, são por sua vez comidos, engolidos pelas vagas do mar ou devorados por seus companheiros. 
Contudo, a vingança não pode mais se efetivar num plano horizontal. Ela precisa de um termo transcendente, ausente do capítulo "Dos Canibais". "Deus", de que esta é a única manifestação no díptico americano dos Ensaios, "permitiu merecidamente que essas grandes pilhagens fossem absorvidas pelo mar no transporte, ou nas guerras civis." O que significa que a reversibilidade da violência já não se dá no seio da História, que consagrou o triunfo dos algozes. Seria necessário sair dela para reencontrar, no plano da vingança divina, o equilíbrio perdido. Mas um tal recurso seria concebível? Vê-se de que modo "Dos coches", continuando "Dos Canibais", inflete a lição da história num sentido pessimista (Bataillon, 1974, p. 45).

\section{A América nasce do Brasil}

É preciso render-se à evidência, ainda que contradiga a cronologia das grandes descobertas: a América, no Renascimento, nasce do Brasil. Pouco importa que Colombo tenha tocado o Novo Mundo nas Bahamas e que se tenha obstinado em reconhecer uma por uma as Grandes e as Pequenas Antilhas, antes de se dirigir à Terra Firme. É do Brasil, visitado anos depois por Vespúcio, que surge a princesa nua e emplumada, com os braços carregados de membros sanguinolentos, que faz sua entrada na galeria prosopográfica dos continentes. ${ }^{23}$ Ao longo de todo o classicismo, a alegoria da América, montada num jacaré ou na carapaça de um tatu gigantesco, é brasileira.

O desconhecimento do conjunto das viagens de Colombo e a fortuna correlativa de Américo Vespúcio explicam parcialmente essa preeminência simbólica do Brasil sobre o restante da América, incluindo o Peru e o México. Além disso, a voga dos índios Tupinambá dessa região, que são os Canibais de Montaigne, deve-se, na França, a razões específicas. 
Desde o início do século, e imediatamente após Pedro Alvares Cabral, dezenas de navios normandos, guiados por pilotos portugueses comprados por altas somas, chegavam a cada ano à costa do Brasil para carregar a madeira vermelha de mesmo nome que se empregava no tingimento de tecidos. Esse comércio ilegal provia as necessidades da indústria têxtil de Rouen, e seu lucro era negociado na bolsa de Anvers. ${ }^{24}$ A entrada solene do rei Henrique II em Rouen, a $1^{\circ}$ de outubro de 1550, pretexto para a exibição, à beira do Sena, das riquezas da vida selvagem, com a ajuda de 50 índios e de 250 marujos, igualmente nus e pintados com jenipapo, apresentou uma festiva demonstração dessa familiaridade já antiga com o Novo Mundo. ${ }^{25}$ Acrescentou-se a esse relacionamento constante, entre os anos 1555 e 1560, a aventura da França Antártica, instalada na entrada da Baía de Guanabara, com suas fecundas decorrências literárias. Testemunhos da qualidade das Singularidades da França Antártica, de André Thevet (1557), e da História de uma viagem, de Jean de Léry (1578), a respeito do Brasil e de seus habitantes, não se encontram nessa época em nenhuma outra literatura européia.

Essa já longa tradição explica o fato de Montaigne abordar o continente americano, em 1580, por um povo aparentemente dos mais rudes e menos importantes da América, antes de dedicar às brilhantes civilizações do México e do Peru as páginas repletas de admiração do capítulo "Dos coches", e as terríveis observações que concluem, em 1588, o capítulo "Da moderação".

Nos Ensaios, o Brasil antropófago não apenas precede o México asteca e o Peru inca, como também informa a descrição destes. Produz-se então, em Montaigne, um fenômeno análogo ao que se observa, na mesma época, na iconografia das grandes descobertas. Um fenômeno de contaminação, que o antropólogo William Sturtevant qualificou de "tupinambização", estende para todo o continente traços étnicos ou culturais próprios dos índios Tupinambá: o machado de pedra polida, 
a "espada" de ponta circular chata e cortante, o escudo de casco de tatu e as diversas "penas" com que os Tupi se enfeitam para suas festas invadem o mapa da América, acompanhando as guerras e danças dos Astecas, dos Peruanos e até dos Huron (Sturtevant, 1976 e 1988). O melhor exemplo dessa uniformização dos Ameríndios, segundo o modelo brasileiro, é a coleção das Grandes viagens de Théodore de Bry. Nos catorze volumes fartamente ilustrados dessa série, cuja publicação se estendeu por quase meio século, de 1590 até 1634, a imagem do Canibal nu, emplumado e tonsurado, com faces e lábios cobertos de incisões, que encontra sua justificação plena na "Terceira parte", consagrada ao Brasil de Hans Staden e Jean de Léry, dissemina-se para as regióes mais afastadas do Novo Mundo, cruzando os Andes com os conquistadores espanhóis e subindo pelo Panamá até os planaltos do Novo México. ${ }^{26}$ Ao termo do processo, o Brasileiro é o Americano.

A "tupinambização" que se percebe em Montaigne, na passagem entre "Dos Canibais" e "Dos coches", é muito menos visível. Montaigne, como apontamos, possuía em seu castelo no Périgord uma coleção de americana - redes, ibirapemas, bastôes de ritmo, todos objetos provenientes do Brasil, e ele sabia disso. Assim, ele não transporta tais artefatos modestos para o meio dos esplendores de Cuzco e México. A “tupinambização" dos mexicanos e peruanos, sem dúvida mais discreta, nem por isso é menos real.

Ela se revela imediatamente na juventude e no estado de inocente nudez que são os atributos primeiros do Novo Mundo. Passa-se, aí, do próprio ao figurado, e de um tipo particular, o Canibal do Brasil, para o Ameríndio em geral. A ausência de "calças" é elevada ao plano da alegoria: trata-se, a partir de então, de um "mundo-criança", "nu no ventre" de sua mãe (Montaigne, 1965, III, 6, p. 908), e não mais deste ou daquele entre seus habitantes naturais. Mas o começo da seção americana de "Dos coches", por si só, é revelador. Montaigne vê a América como 
um todo por meio do paradigma brasileiro, bem conhecido por ele desde 1580. A retomada da "fórmula negativa" entre um ensaio e outro "nem letras, nem pesos, nem medidas, nem roupas, nem trigo, nem vinhas" (ibid.) - mostra que a dimensão primitivista permanece na base desse novo capítulo americano.

Mais adiante, muito embora tenha acabado de louvar a "indústria" refinada dos mexicanos, expressa em sua ourivesaria, em sua tecelagem, em suas pinturas e em seus quadros de penas, Montaigne emprega sem transição a expressão "povos nus” em relação aos índios que enfrentam espanhóis vestindo armaduras e armados dos pés à cabeça (id., p. 909). Tais soldados nus são, evidentemente, soldados sem armas, ou tão pouco armados que acabam impotentes diante dos cristãos "possuidores de uma pele brilhante e dura”, guerreiros da idade do ferro. Mas a nuance que Montaigne imediatamente introduz no quadro, ao precisar que "a invenção de um tecido de algodão" chegou a certos lugares do Novo Mundo, ${ }^{27}$ indica claramente que ele considera a nudez em sua acepção mais literal.

O contraste entre nu e vestido, na iconografia relativa à Conquista, representa um verdadeiro topos plástico, que remonta à primeira metade do século. Já aparente na "Paisagem das Índias Ocidentais", do holandês Jan Mostaert, e de saída carregado de intenções alegóricas, ${ }^{28}$ foi mais tarde sistematizado na coleção das Grandes viagens, de Théodore de Bry. ${ }^{29}$ Esse contraste dramático entre a carne indefesa e o ferro assassino costuma ocorrer sobre um fundo de tranqüilidade, em que passeiam livremente os animais do Éden. Em Montaigne, ele é inseparável da visão primeira do mundo-criança no seio materno e leva naturalmente, na seqüência do ensaio, à imagem da natureza selvagem, que os europeus, como bons pedagogos, deveriam ter-se esforçado em "polir" e "desbastar". Conformada à figura idealizada do Brasileiro, a alegoria da América, nua e inocente, informa por sua vez a representação homogenei- 
Revista de Antropologia, São Paulo, USP, 2006, v. 49 no 2.

zada de todas as nações que a povoam. O Americano, terreno novo repleto de "boas sementes que a natureza aí tinha produzido" (Montaigne, 1965, III, 6, p. 910), ${ }^{30}$ caracteriza tanto a sociedade dos Canibais, muito próxima de sua "simplicidade original", quanto o mundo-criança de Astecas e Incas.

A tupinambização, obtida por associação e fusão entre os exemplos acima, pode igualmente resultar de uma seleção do material etno-histórico. O melhor exemplo de censura é apresentado pela religião dos Astecas, sangüinária e cruel, refinada e demonstrativa. Para respeitar a economia de seu requisitório contra os excessos da Conquista, Montaigne isola esses elementos incômodos, presentes em fontes (Cortez, Gomara) utilizadas por ele em "Dos coches", relegando-os ao fim do capítulo "Da moderação" num longo acréscimo à redação, mais ou menos da mesma época (id., I, 30, p. 201). É esse o preço da preservação da unidade das novas terras, "puras e ainda virgens em comparação com as nossas" (ibid.).

Vê-se, assim, como a discreta tupinambização operada por Montaigne logra unificar o Novo Mundo. Entretanto, essa unidade histórica, geográfica e antropológica não desemboca numa simplificação da imagem do índio, nem tampouco na eliminação completa de suas contradiçóes. Muito pelo contrário. O Novo Mundo é tanto uno quanto contraditório. $\mathrm{O}$ modelo do livre e orgulhoso Canibal se generaliza a toda a área ameríndia, mas também passa a conter traços díspares, antitéticos até, tal como sobriedade e luxo, ignorância e competência admirável, nudez e ricas vestimentas, casas rústicas cobertas de palha e monumentais cidades de pedra, com palácios e jardins, cujas árvores, frutos e grama são de ouro.

No momento em que Montaigne compunha o capítulo "Dos coches", existia, no entanto, uma grade classificatória que lhe teria permitido resolver essas flagrantes contradições. Em 1588, justamente, foi 
publicado em Salamanca o De procuranda Indorum salute, do jesuíta José de Acosta, tratado de missiologia que distingue três categorias de "bárbaros", segundo seu grau de convertibilidade. Os "bárbaros selvagens" do Brasil e do Caribe, que vivem nus e em bandos, devem ser duramente combatidos, de modo que seus corpos abatidos sirvam de tábula rasa para a inscrição da verdade do Evangelho. Por outro lado, as naçôes mais policiadas do México e do Peru, cuja organização política é notável, mas que desconhecem a escrita, receberão tratamento mais clemente. Finalmente, os pagãos que possuem civilizações brilhantes e tradição escrita serão trazidos à religião cristã pela brandura e pela persuasão. ${ }^{31}$ Ainda que ele tivesse lido Acosta, rapidamente divulgado em toda a Europa, é pouco provável que Montaigne recorresse a essa tipologia simplificadora, cujo desígnio manifesto era a redução do outro ao idêntico, ou seja, seu aniquilamento.

\section{Roma e México}

Em Montaigne, a tupinambização tem como corretivo e contrapeso a "romanização" desses mesmos americanos, o que aumenta a complexidade do que acabamos de descrever. Na verdade, até agora não consideramos o capítulo "Dos coches" como um todo, destacando arbitrariamente sua seção final, relativa à conquista e destruição do Novo Mundo, o que equivale a menos de um terço do conjunto. Mas o capítulo fala de outra coisa: primeiramente, dos meios de transporte, veículos de todo tipo, como indica seu título. Da idéia de locomoção, designada obliquamente pelo título, passa-se, no decorrer do ensaio, para a experiência da instabilidade, "mal-estar físico agravado em angústia diante das transformações do mundo e, então, recomposto, feito indignação contra seus agentes históricos" (Tournon, 1988, p. 925). 
"Dos coches", isto é, "Dos veículos"; pode-se dizer que Montaigne os coleciona. "Dos coches" é uma coleção de automóveis, uns mais excêntricos que os outros. $\mathrm{O}$ ensaio, em suas primeiras páginas, e se nos ativermos a uma leitura superficial, remete aos catálogos de invençóes singulares, tão apreciados pelo público do século XVI. Essa moda dos inventores, que deu origem ao gênero da "heurematografia", cuja expressão mais completa e mais rica é o De inventoribus do humanista Polidoro Virgílio (ver Copenhaver, 1978), remonta à Antiguidade. Sêneca já denunciava, em De brevitate vitae, essa busca insensata por um saber inútil, doença, segundo ele, herdada dos gregos:

Há alguns dias, escutei uma apresentação acerca do que cada um dos generais romanos fora o primeiro a fazer: Dullius foi o primeiro a obter uma vitória naval; Curius Dentatus, o primeiro a desfilar com elefantes em seu triunfo. [...] Parece-te oportuno preocupar-se em saber que Sila foi o primeiro a soltar leões na arena, quando antes eles permaneciam amarrados, e que o rei Bocus mandou arqueiros para matá-los? Ainda isso, que seja. Mas saber que Pompeu foi o primeiro a oferecer como espetáculo um combate de circo opondo dezoito elefantes a condenados, pode isso ter alguma conseqüência feliz? [...] Pois admitindo que contém de boa-fé todas essas histórias e se apresentem como testemunhas, os descaminhos de quem, afinal, poderão elas atenuar? [...] Nosso grande Fabiano reconhecia que, por vezes, se perguntava se não seria preferível a tais inépcias não se dedicar a estudo algum. (Sêneca, 1995, XIII, 3-9, pp. 125-6)

Essa lista de invenções contestáveis faz pensar no catálogo de carros com atrelagens estranhas que Montaigne apresenta no início do capítulo "Dos coches": "Marco Antonio foi o primeiro a ser conduzido em Roma, com uma rapariga-menestrel, por leões atrelados a um coche. Heliogabalus fez mais tarde o mesmo, dizendo-se Cibele, a mãe dos 
deuses, e também atrelados por tigres, imitando o deus Baco" (Montaigne, 1965, III, 6, p. 901) etc.

Em seguida, introduzidos pela menção às feras subjugadas, vêm os jogos do circo, ou seja, exatamente o exemplo utilizado por Sêneca para ridicularizar o inútil saber dos "inventores". Mas Montaigne não se escandaliza demais com a "estranheza de tais invençôes" (id., p. 902). Muito pelo contrário, ainda que condene o gasto exagerado, não pode deixar de admirar o espetáculo:

Era contudo uma bela coisa levar e plantar na praça das arenas uma grande quantidade de árvores grandes, frondosas e bem verdes, representando uma grande floresta densa, disposta em bela simetria, e, no primeiro dia, lançar nela mil avestruzes, mil cervos, mil javalis e mil gamos, deixando-os pilhar o povo. E no dia seguinte, fazer espancar em sua presença cem leões grandes, cem leopardos e trezentos ursos, para no terceiro dia fazer combater até a morte trezentos pares de gladiadores, como fez o imperador Probus. Eram também coisa bela de se ver os grandes anfiteatros, com o exterior recoberto de mármore, lavrado de obras e estátuas, com o interior reluzente de raros ornamentos. (id., p. 905)

Em Montaigne, como em Justo Lipsio, autor de De Amphiteatro, em que essa passagem se inspira diretamente, ${ }^{32}$ "admiração" é a palavra de ordem. É o que escusa a pesquisa inútil que Sêneca lamentava:

Se algo é escusável em tais excessos, reside no que a invenção e a novidade motivam em termos de admiração, não no gasto. (id., p. 907)

Fúteis, Justo Lipsio e Montaigne? Insensatos, seu gosto pelo catálogo e sua busca apaixonada dos fatos admiráveis dos antigos? $\mathrm{Na}$ verdade, em ambos os casos, a admiração é inseparável de uma meditação 
acerca da História. A visão de um anfiteatro em ruínas é uma boa entrada para meditar acerca do teatro do mundo, lugar-comum que goza de uma voga extraordinária no final do século XVI. O tratado dialogado de Justo Lipsio, que é uma visita guiada pelo Coliseu, ornamentada com citações de autores antigos, cujas afirmações são corrigidas quando é o caso, começa, assim, por um lamento sobre as ruínas de Roma, logo transformado em exercício de admiração. Nicolau Florentius, em vez de se lamuriar, convida seu interlocutor a ver nos vestígios a presença ainda viva da Roma Antiga. ${ }^{33}$ De modo que, no decorrer desse passeio melancólico, o desgosto inicial vai pouco a pouco dando lugar ao entusiasmo.

Para Montaigne, tampouco a Antiguidade está morta. Ainda respira nos livros, e nas cidades do Novo Mundo, recentemente pilhadas e arrasadas pelos conquistadores. Aqui, porém, a relação entre melancolia e admiração toma o caminho inverso: a admiração pelos Antigos é primeira, sua superioridade, atestada por historiadores e poetas, é da ordem da evidência. Montaigne diz isso, aliás, no capítulo "Da grandeza romana” (id., II, 24, pp. 686-7), por exemplo, e repete-o aqui. Dizer que Montaigne adere sem reservas às afirmações de Justo Lipsio é pouco: "Nessas mesmas vaidades descobrimos o quanto aqueles séculos eram férteis de espíritos diferentes dos nossos" (id., III, 6, ad loc). A admiração pelos Antigos leva à depreciação dos Modernos, e, mais além, à clara indignação diante deles. Os Modernos não apenas são incapazes de rivalizar em engenho com Gregos e Romanos, como exterminaram e destruíram povos que reviviam a generosidade e a grandeza destes. Daí a famosa exclamação em que se encontram a Antiguidade e o Novo Mundo, o afastado no tempo e o afastado no espaço:

Antes tivesse cabido a Alexandre ou aos antigos gregos e romanos tão nobre conquista, e tão grande mutação e alteração de tantos impérios e povos, em mãos que teriam delicadamente polido e desbastado o que havia 
de selvagem e teriam protegido e estimulado as boas sementes que a natureza ali tinha produzido. (id., p. 910)

Montaigne viu o Coliseu em sua viagem à Itália, mas não diz uma palavra a esse respeito em "Dos coches". É muito provável que, ao compor esse capítulo, tivesse diante dele as pranchas gravadas do tratado de Justo Lipsio, que representam com grande luxo de detalhes o anfiteatro de Tito em seu antigo esplendor, quando, em volta do altar de Júpiter, tinham lugar combates de gladiadores e justas eqüestres, e sua aparência atual, de ruína coberta de arbustos e sobrevoada por pássaros. ${ }^{34}$ Seu pensamento não é contudo guiado pelo espetáculo permanente das ruínas romanas. O que guia Montaigne e alimenta seus devaneios é uma lista, um desfile de fantasmas, uma acumulação litânica de espetáculos tão insólitos quanto efêmeros, de que chega a nós apenas o rumor embelezado pelos poetas antigos.

Essa variação sobre o Ubi sunt nada tem inicialmente de tristonho ou melancólico. Montaigne se encanta como uma criança. Mas a repetição contínua abre um abismo. No capítulo "Dos coches”, o duplo desfile de carruagens e os jogos do circo são seguidos por uma meditação acerca do movimento da História e da instabilidade dos impérios. Ao termo da enumeração, revela-se em sua tenebrosa extensão a ruína do Novo Mundo, simbolizada nas últimas linhas do capítulo pela queda do Inca Atahualpa de seu trono levado por carregadores, na funesta noite de Cajamarca, a 16 de novembro de 1532 . O prazer pueril da lista, ou o que assim pode nos parecer, desemboca numa meditação vertiginosa, em que se selam a sorte dos povos e o destino do mundo. A acumulação, o excesso lúdico, o crescendo de espanto em espanto, o lado "livro dos recordes" dessa exibição de erudição, que ocupa dois terços do capítulo, desaguam numa visão das mais sombrias, por eles preparada e alimentada, e ao mesmo tempo afastada, assim como os quatro 
Revista de Antropologia, São Paulo, USP, 2006, v. 49 no 2.

primeiros atos de uma tragédia simultaneamente afastam e preparam a catástrofe inelutável.

Nas filigranas de México e Cuzco, e de "sua assombrosa magnificência", encontram-se, assim, o Coliseu romano e as ruínas de Roma, descritas por Justo Lipsio em De Amphiteatro. Desse modo se sobrepõem, no Novo Mundo de Montaigne, duas operações aparentemente contraditórias: a "tupinambização" do México e do Peru se insere num quadro "romanizado". Astecas e Incas são romanos que teriam conservado a simplicidade dos costumes dos Canibais, povos naturistas instalados numa arquitetura colossal de pórticos e arenas, circos e pirâmides, antes da destruição dessas cidades ideais por Bárbaros armados de ferro.

Daí a montagem espantosa e algo surrealista: povos nus, ornados unicamente de penas, são integrados num cenário urbano geométrico e refinado para compor uma espécie de prenúncio de Paul Delvaux. Em lugar de moçoilas descabeladas, com grandes olhos, perambulando por estações de trem, são povos-criança, recém-saídos do Éden para colonizar, com suas sombras etéreas, traçados arquitetônicos inexplicavelmente surgidos do passado. Antes mesmo da publicação das Grandes viagens de Théodore de Bry e seus filhos, a partir de 1590, ou seja, na década seguinte à morte de Montaigne, este imaginava o "teatro do Novo Mundo" tal como o inventaria então o Ocidente em crise (ver Bouyer \& Duviols, 1992) - teatro trágico, no qual, sobre um fundo de palácios e pirâmides, povos nus, que até então brincavam, dançavam e se divertiam, repentinamente agonizam, degolados, queimados vivos ou supliciados por invasores de barba e elmo, com os traços e as roupas de ferro dos espanhóis.

Duas nostalgias se encontram aqui, a da idade de ouro e a da grandeza antiga, ambas simultaneamente destroçadas pela violência absurda e vil da Conquista. De um mesmo e único golpe, a realidade de uma Europa mercantil e degenerada põe fim a um duplo sonho de restituição. 
Roma e México tinham em comum o fato de não serem nem "mecânicas" nem venais. Ambas possuíam o senso do esplendor e do gasto ostentatório, como atestam o circo romano, os animais, os jardins e a pompa dos últimos imperadores astecas. Daí a cólera do pedagogo e do humanista em Montaigne:

Quem jamais tanto valorizou o serviço do mercadejo e do tráfico? Tantas cidades arrasadas, tantas nações exterminadas, tantos milhões de povos massacrados, e a mais rica e mais bela parte do mundo destruída em nome do negócio de pérolas e pimenta: Mecânicas vitórias! (Montaigne, 1965, III, 6, p. 910)

Para Montaigne, a descoberta do Novo Mundo era a ocasião inesperada de captar no presente a Antiguidade viva. Pois essa Antiguidade grandiosa, multiforme e variegada vivia ainda do outro lado do oceano. Estava, por assim dizer, ao alcance da mão. No presente, só estava separada pelo estreito de um mar facilmente atravessável, graças aos recentes progressos da navegação que a tinham aproximado como nunca dantes. Bastava estender-lhe o braço para que retornasse a nós e nos comunicasse sua grandeza intacta e, assim, podia ser conjurada a maldição atrelada ao esquecimento e ao tempo, que tudo devora. A História fornecia ao Ocidente, desse modo, uma formidável elipse espaço-temporal que lhe teria permitido reinscrever a herança antiga em seu presente. Mas eis que, recém-surgido no horizonte dos mares, tal milagre era mortalmente atingido, ignominiosamente destruído por quem não soubera compreender-lhe a grandeza nem a chance única que se lhe apresentava. E a Antiguidade foi mais uma vez perdida. Agora, irremediavelmente.

Essa é a grande visão subjacente ao capítulo "Dos coches". Montaigne não se enluta exclusivamente por metade da humanidade. É bem pior, pois se trata ao mesmo tempo de luto por todo o passado do mundo, 
Revista de Antropologia, São Paulo, USP, 2006, v. 49 no 2.

ou, mais precisamente, por tudo o que há de mais grandioso, nobre e extraordinário na memória da humanidade. "Dos coches", ou o sonho duas vezes perdido do Renascimento.

Evidentemente, não há entre a Antiguidade e o Novo Mundo nem identidade nem igualdade estrita, ainda que fosse apenas em razão do caráter móvel de sua relação. Ora - e é essa a idéia que parece dominar a maior parte do texto - a Antiguidade é apresentada como o pedagogo, como o colonizador ideal, portanto, de um Novo Mundo reduzido ao estatuto de criança e aprendiz, certamente promissor, mas que convém doutrinar com urgência exatamente por isso; uma criança que é preciso cobrir de exemplos em vez de golpes, diz-nos Montaigne, mas que evidentemente deve ser educada, ou aperfeiçoada. Ora, ao contrário, o Novo Mundo já rivaliza com a Antiguidade por suas invenções. Os jardins de plantas de ouro e os animais de ouro da capital do México nada deixam a desejar ao esplendor do anfiteatro de Tito, "coberto" de mármore, nem a suas florestas artificiais, plantadas para espetáculos efêmeros. ${ }^{35} \mathrm{E}$ eis que a estrada pavimentada de trezentas léguas que leva de Quito a Cuzco, atravessando cadeias de montanhas inacessíveis e despenhadeiros, supera em magnificência e utilidade tudo o que a Antiguidade jamais concebeu de grandioso. "Nem a Grécia, nem Roma, nem o Egito" jamais viram nada assim (Ménager, 1993). De modo que a relação entre a Antiguidade e o Novo Mundo oscila constantemente entre a pedagogia e a emulação. In extremis, logo antes da queda, no sentido próprio e figurado, que encerra o capítulo, o Novo Mundo quase se torna preceptor do Velho por uma inversão da hierarquia até então implicitamente aceita, apesar das repetidas críticas dirigidas aos "de cá".

Além disso, do mesmo modo que o ameríndio de Montaigne resulta da sobreposição de imagens dificilmente compatíveis, para finalmente gerar um híbrido, inca ou mexicano "tupinambizado", a Antiguidade apresenta, nesse capítulo, uma hibridação comparável. A época histórica 
de referência varia constantemente. A escala de medida é ora fornecida pela Antiguidade heróica e virtuosa dos começos, ora pela Antiguidade pervertida da decadência: a juventude exemplar e conquistadora de Alexandre e da República romana, ou o declínio e decrepitude de imperadores mergulhados em orgias, inebriados por gastos suntuários e espetáculos jamais vistos. De todo modo, qualquer que seja a etapa de desenvolvimento considerada, essa Antiguidade sintética faz empalidecer nossa modernidade por seu luxo e seu brilho. A essas duas imagens da Antiguidade, ${ }^{36}$ acrescenta-se uma terceira, agora mítica, da idade de ouro e do idílio, quando a humanidade, despreocupada e nua, sem pena e sem trabalho, vivia dos frutos que a terra lhe oferecia em profusão. Constata-se que essa terceira imagem converge de modo bastante exato com a tupinambização de Astecas e Incas.

Conseqüentemente, a Antiguidade e a América se apresentam no mesmo plano, unidas por uma série de afinidades: o Canibal do Brasil possui as virtudes viris de Esparta, e a capital do México, a grandiosidade e o luxo da Roma imperial. Essas duas grandes figuras que se espelham, do alto de sua formidável magnitude, colocam em seu devido lugar a modernidade de europeus indignos dessa dupla herança, a herança do tempo e da História e o legado inesperado do espaço ampliado.

\section{Notas}

1 Como Todorov (1989, pp. 51-64), por exemplo.

2 Acerca da "fórmula negativa", figura privilegiada e obrigatória do discurso primitivista, ver Levin (1970, p. 11), Defaux (1987, p. 172), Marouby (1990, pp. 113-26).

3 A perspectiva aqui adotada é tangente à que essa obra delineia.

4 Acerca das relações entre a Servidão de La Boétie e "Dos Canibais", ver Lestringant (1994, pp. 181-3). 
5 Para essa aproximação, ver Mahlke (2003).

6 Les louanges de la Folie, op. cit., 1566, f. C6vo.

7 Ibid., f. C7ro.

$8 \mathrm{Se}$, como Montaigne, contarmos como primeiro andar o térreo, onde se encontra a capela.

9 Em Legros (2000), ver a prancha 40, "Plano do teto da 'livraria' de Montaigne", em face da página 257.

10 Ver Certeau (1981, pp. 193-6).

11 Cf. Montaigne (1965, I, 31, 213 A).

12 Artigo resumido e comentado por Dosse (2002, p. 533).

13 "Primeiramente, não resta dúvida, creio, de que, se vivêssemos com os direitos que nos deu a natureza e com seus ensinamentos, seríamos naturalmente obedientes aos pais, sujeitos à razão e servos de ninguém."

14 A gabela era um imposto sobre o sal instituído na Idade Média, e abolido apenas na Revolução Francesa. Várias revoltas eclodiram na França em torno dessa taxa, algumas especialmente longas e violentas. [N.T.]

15 A julgar pelo que afirma o historiador Jacques-Auguste de Thou, Historia sui temporis, V, XIII, que colheu as confidências de Montaigne a esse respeito. Ver a introdução de Malcom Smith à edição citada da Servidão voluntária (La Boétie, 1987, pp. 7-10).

16 Retomo essa expressão de meu livro Le Cannibale, grandeur et décadence (1994, cap. 8, pp. 177-97).

17 Como crê Hoffmann (2002, p. 213).

18 Ou 1579-1587 se considerarmos a data de sua redação, conforme a cronologia proposta por Pierre Villey.

19 Ler, a esse respeito, Nakam (1984, pp. 329-51).

20 É preciso corrigir, quanto a isso, a nota 8, na página 212 da edição de Pierre Villey, em que se inspira a recente edição dos Ensaios em "Pochothèque" (Paris, LGF, 2001, p. 330, nota 3). Não se trata de "descrições", mas, como sugere Montaigne, efetivamente de "pinturas", ou melhor, gravuras. Ver, a título de comparação, Thevet $\left(1557,76 v^{\circ}\right)$, Lestringant (1997, p. 162) e Léry (1578 e 1580, p. 214 in 1994, p. 367).

21 Ver ilustração.

22 "Assim, há derrotas que vencem vitórias." 
23 Acerca das alegorias dos quatro continentes no Renascimento, ver Margolin (1982) e Zavala (1984).

24 Como nos informa Louis Guichardin (Ludovico Guicciardini), "Como a França aprovisiona Anvers": "e grande quantidade de Brasil que os franceses, com grande risco de suas vidas, vão até a América buscar, no país que (como alhures dizemos) pertence aos portugueses, embora os franceses tenham lá construído pouso e morada, tendo edificado uma bela fortaleza" (1582, p. 189). A fortaleza fora tomada a 16 de março de 1560 .

25 Sobre essa famosa entrada, ver Massa (1975) e Lestringant (1984).

26 Acerca dessa coleção, publicada em Frankfurt por um impressor e gravador refugiado, originário de Liège, e por seus filhos, ver Bucher (1977) e Duchet et al. (1987).

27 "[...] e então, contra povos nus, a não ser onde chegara a invenção de um tecido de algodão" (ibid.).

28 O quadro, conservado no Museu Frans Hals de Haarlem, data das vizinhanças de 1542 e possivelmente remete à expedição de Coronado ao Novo México. Ver reprodução e comentário no catálogo de Hugh Honour (1976, pp. 12-4).

29 Ver, especialmente, as partes IV a VI. Várias reproduções se encontram em Michèle Duchet et al. (1987, pp. 193-219).

30 Cf. Montaigne (1965, I, 31, p. 206).

31 Acerca da obra apologética e missiológica do padre Acosta, ver o estudo clássico, que por vezes se aproxima da hagiografia, de Dainville (1940, pp. 150-3), bem como a tese de inspiração marxista de Gliozzi (1977, pp. 371-81).

32 Caput primum: "Urbs diruta, non diruta: et splendidae eius ruinae" (Justo Lipso, 1584).

33 "Scilicet haec ipsa ruta et caesa spirant etiam Romam veterem et velut scintillas emittunt prisci splendoris" (Justo Lipsio, 1584, c. I, p. 11).

34 "Amphiteatri interior facies qualem eam fuisse cum omnibus membris suspicamur" (Justo Lipsio, 1584, após página 61) e "Amphiteatrum Titi” (id., pp. 24-5).

35 Essa aproximação é sugerida por Croquette (1985, p. 39).

36 Imagens que foram apontadas por Croquette (1985, p. 43). 
Revista de Antropologia, São Paulo, USP, 2006, v. 49 no 2.

\section{Bibliografia}

BATAILLON, Marcel

1959 "Montaigne et les conquérants de l'or", Studi francesi, III, 9, set.-dez.

1974 "L'Amiral et les 'nouveaux horizons' français", Actes du colloque L'Amiral de Coligny et son temps (oct. 1972), Paris, Société de l'Histoire du Protestantisme Français.

BOUYER, Marc \& DUVIOLS, Jean-Paul (orgs.)

1992 Le théatre du Nouveau Monde. Les grands voyages de Théodore de Bry, Paris, Gallimard.

BRY, Théodore de

1592 Americae tertia pars, provinciae Brasiliae historiam continens, ed. de Hans Staden e Jean de Léry, Frankfurt. [Tradução alemã: Dritte Buch Americae, darinn Brasilia [...] auss eigener erfahrung in Teutsch beschrieben, Frankfurt, 1593.]

BUCHER, Bernadette

1977 La sauvage aux seins pendants, Paris, Hermann.

CAILLOIS, Roger

1947 "Prefácio a Montesquieu", Oeuvres complètes, Paris, Gallimard, "Bibliothèque de la Pléiade”.

CERTEAU, Michel de

1981 "Le lieu de l'autre. Montaigne: 'Des Cannibales'”, in Le racisme, mythes et sciences. Pour Léon Poliakov, Paris.

1985 "Histoire et anthropologie chez Lafitau", in BLANCKAERT, Claude (org.), Naissance de l'ethnologie?, Paris, Éditions du Cerf.

CHOMARAT, Jacques

1981 Grammaire et rhétorique chez Érasme, Paris, Les Belles Lettres. 
CLASTRES, Pierre \& LEFORT, Claude

1976 "Apêndice a Étienne de la Boétie", in Le Discours de la servitude volontaire, Paris, Payot. [Edição brasileira: "Liberdade, mau encontro, inominável", in CLASTRES, P. Arqueologia da violência, trad. Paulo Neves, São Paulo, Cosac \& Naify, 2004.]

COPENHAVER, Brian P.

1978 "The Historiography of Discovery in the Renaissance: the sources and composition of Polydore Vergil's De inventoribus rerum, I-III", The Journal of the Warburg and Courtauld Institutes, vol. 41, pp. 192-214.

CROQUETTE, Bernard

1985 Étude du Livre III des "Essais" de Montaigne, Paris, Champion "Unichamp".

DAINVLLE, François de

$1940 \quad$ La géographie des humanistes, Paris.

DANDREY, Patrick

1997 L'éloge paradoxal de Gorgias à Molière, Paris, PUF.

DEFAUX, Gérard

1987 Marot, Rabelais, Montaigne: l'écriture comme présence, Paris, Champion.

DOSSE, François

$2002 \quad$ Michel de Certeau. Le marcheur blessé, Paris, La Découverte.

DUCHET, Michèle et al.

1987 L'Amérique de Théodore de Bry, Paris, Éditions du CNRS.

FUMAROLI, Marc

1972 "Microcosme comique et macrocosme solaire: Molière, Louis XIV et l'Impromptu de Versailles", Revue des Sciences Humaines, t. XXXVII, n. 145: 95-114, jan-mar. 
Revista de Antropologia, São Paulo, USP, 2006, v. 49 no 2.

GLIOZZI, Giuliano

1977 Adamo e il nuovo mondo. La nascita dell'antropologia come ideologia coloniale: dalle genealogie bibliche alle teorie razziali (1500-1700), Florença, La Nuova Italia.

GUICHARDIN, Louis (Ludovico Guicciardini)

1582 Description de tous les Pais-Bas, autrement appellés la Germanie inferieure, ou Basse Allemagne, Anvers, Cristophe Plantin.

HOFFMANN, George

2002 "Anatomy of the Mass: Montaigne’s Cannibals", PMLA, vol. 117(2), Mar.

HONOUR, Hugh

1976 L'Amérique vue par l'Europe, Paris, Éditions des Musées Nationaux.

JUSTO LIPSO

1584 Iusti Lipsi De Amphiteatro Liber. In quo forma ipsa Loci expressa, et ratio spectandi. Cum aeneis figuris, Antuérpia, C. Plantin.

LA BOÉTIE, Étienne

1987 De la servitude volontaire ou Contrun, introdução e notas por Malcom Smith, Genebra, Droz, 'TLF'. [Edição brasileira: Discurso da servidão voluntária, trad. Laymert Garcia dos Santos, São Paulo, Brasiliense, 1982.]

LAFOND, Jean

1984 "Le discours de la servitude volontaire de La Boétie et la rhétorique de la déclamation", Mélanges sur la littérature de la Renaissance à la mémoire de V. L. Saulnier, Genève, Droz.

LEGROS, Alain

2000

Essai sur poutres. Peintures et inscriptions chez Montaigne, Paris, Klincksieck.

LÉRY, Jean de

1578-1580 Histoire d'un voyage faict en la terre du Brésil, Genebra, A. Chuppin.

1994

Histoire d'un voyage faict en la terre du Brésil, organização, apresentação e notas de F. Lestringant, Paris, LGF, "Bibliothèque classique". [Edição brasileira: Viagem à terra do Brasil, Belo Horizonte/São Paulo, Itatiaia/Edusp, 1980.] 


\section{LESTRINGANT, Frank}

1984 "Rouen et les 'nouveaux horizons", in PARENT, Alain (org.), La Renaissance et le Nouveau Monde, Québec, Musée du Québec.

1994 Le Cannibale, grandeur et décadence, Paris, Perrin. [Edição brasileira: O canibal: grandeza e decadência, trad. M. M. Del Priore, Brasília, Editora Universidade de Brasília, 1997.]

1997 Le Brésil d'André Thevet. Les singularités de la France Antarctique, Paris, Chandeigne.

LEVIN, Harry

$1970 \quad$ The Myth of the Golden Age in the Renaissance, Londres, Faber \& Faber.

LOPES DE GOMARA, Francisco

Histoire générale des Indes Occidentales, trad. Martin Fumée, Paris, M. Sonnius.

MAHLKE, Kirsten

2003

"Indianer und Narren. Zur karnavalesken Rezeption von Jean de Lérys Histoire d'in voyage fait en la terre du Brésil", in SCHLEISER, R. \& ZELLMANN, U. (orgs.), Reisen über Grenzen. Kontakt und Konfrontation, Maskerade und Mimikry, Münster/Nova York/Munique/Berlim, Waxmann.

MARGOLIN, Jean-Claude

1982 "L'Europe dans le miroir du Nouveau Monde", in La conscience européenne au XVe et au XVIe siècle, Paris, Collection de l'Ecole Normale Supérieure de Jeunes Filles.

MAROUBY, Christian

1990 Utopie et primitivisme. Essai sur l'imaginaire anthropologique à l'àge classique, Paris, Seuil.

MASSA, Jean-Marie

1975 "Le monde luso-brésilien dans la Joyeuse Entrée de Rouen", in Les fêtes de la Renaissance, t. III, Paris, Éditions du CNRS. 
Revista de Antropologia, São Paulo, USP, 2006, v. 49 no 2.

\section{MONTAIGNE}

1965

Essais, ed. Pierre Villey, Paris, PUF.

NAKAM, Géralde

1984 Les Essais de Montaigne, miroir et procès de leur temps, Paris, Nizet.

QUIGNARD, Pascal

1990 Albucius, POL e Le Livre de Poche.

SÊNECA

1995 De brevitate vitae, Ed. Arléa. [Edição brasileira: Sobre a brevidade da vida, trad. William Li, São Paulo, Novalexandria, 1993.]

STADEN, Hans

Wahrhaftige Historia und Beschreibung eyner Landtschafft der wilden, nacketen, grimmigen Menshfresser, Leuthen in der Neuenwelt America gelegen, Marburg, A. Kolbe. [Edição brasileira: Duas viagens ao Brasil, Belo Horizonte/São Paulo, Itatiaia/Edusp, 1974.]

STAROBINSKI, Jean

1982

Montaigne en mouvement, Paris, Gallimard. [Edição brasileira: Montaigne em movimento, trad. M. L. Machado, São Paulo, Companhia das Letras, 1992.]

STURTEVANT, William C.

1976

"First Visual Images of Native America", in CHIAPPELLI, F. (org.), First Images of America. The impact of the New World on the Old, Berkeley/Los Angeles, University of California Press.

1988 "La 'tupinambisation' des Indiens d'Amérique du Nord”, in THÉRRIEN, G. (org.), Les figures de l'indien, Montréal, UQAM.

THEVET, André

Les singularitez de la France Antarctique, Paris. [Edição brasileira: As singularidades da França Antártica, Belo Horizonte/São Paulo, Itatiaia/Edusp, 1974.]

TODOROV, Tzvetan

1989

Nous et les autres, Paris, Seuil. 
TOURNON, André

Montaigne. La glose et l'essai, Lyon, Presses Universitaires de Lyon.

1988

"Tout dire ou tout désigner", Revue d'histoire littéraire de la France, 88e. année, n. 5.

ZAVALA, Huguette

1984

"L'allégorie de l'Amérique au XVIe siècle", in PARENT, Alain (org.), La Renaissance et le Nouveau Monde, Québec, Musée du Québec.

ABSTRACT: This article proposes a new perspective on Montaigne's celebrated essays on America and its peoples, initially in the light of the rethorical form of declamation adopted in them. The comparison of the "American" Essays reveals, moreover, the privileged place of Brazil and its Cannibals in Montaigne's reflection on the New World, and the compositon of an image of all of its peoples that is simultaneously conformed to the edenic model of the Tupinambá and elevated to the dignity of Antiquity's great men - "tupinambized" and "romanized".

KEY-WORDS: Montaigne, Amerindians, declamation, primitivism, Tupinamba, Bon Sauvage, cultural relativism, philosophy of history

Tradução de Beatriz Perrone-Moisés.

Aceito em novembro de 2006. 